\title{
At samle på lyde
}

Blandt de første ting, jeg begyndte at samle på, var muslingeskaller og konkylier. Disse forunderlige variationer over et simpelt grundmønster fascinerede mig som barn. Jeg gentog sådan set indsamlingens historie i Europa, for i den tidlige renæssance var det præcis de samme ting, som endte i diverse fyrsters og potentaters allerførste raritetskabinetter. Denne fascination overførte jeg til musik og sang fra alverden. I de tidlige teenageår begyndte jeg at samle på grammofonplader med musik fra hele verden, stærkt hjulpet på vej af en grammofonpladehandler på Ryesgade i Århus. hvor man kunne købe musik fra alle verdens riger og lande. Denne forunderlige pladebutiks beskedne størrelse stod ikke i noget rimeligt forhold til dens enorme udbud af musik. Det var i lp'ens storhedstid fra 1960 til 80, hvor der pludselig kom tekniske muligheder for at repræsentere verdens musik ordentligt. Jeg var så heldig at opleve den periode, hvor man kunne samle på musik fra hele verden. Der var ikke den plet på kloden, som ikke var repræsenteret. Det var fra de mest ydmyge steder, de største overraskelser kom: Afrikanske pygmæers simple, men utroligt stærke musik var en åbenbaring, som lærte mig én ting: der findes ikke primitiv musik eller primitive folk. Med en blanding af vokal og kun én fløjtetone kan en pygmæsanger skabe et fuldstændig hypnotisk musikalsk udtryk.

Siden fulgte en udforskning af musik fra alle lande og folk. Jeg lyttede til japansk gagaku hofmusik, indisk klassisk musik, ekstatisk sang fra Azerbaidjan, gamelan musik fra Indonesien. Ligesom den tidligere samling af muslingeskaller og konkylier viste denne samling af musik, at simple grundformer kan føre til en uendelighed af skønhed og variation. Musikindsamlingen lærte mig, at alle verdens folk behersker musik og sang, og deres måder at udnytte mulighederne i vokal- og instrumentalmusik er forunderlige og fulde af endeløse overraskelser. Det gav mig en indgang til at forstå og udforske andre folk, kulturer og samfund. Men for at kunne få dette udbytte af en sådan indsamling må man kunne lytte til fremmed musik og sang. Alle kan betragte og glæde sig over de smukke former i muslingeskaller og konkylier, men desværre er det sådan, at de fleste menneskers ører ,lukker af“ for fremmede musikudtryk efter de atten år. Det var mit store held, at jeg fik lukket ørerne op på et så tidligt tidspunkt, at jeg fik lov at erfare den skønhed, der findes i menneskehedens udtryk i musik og sang. Desværre regner mange antropologer musik og sang for uvæsentlige områder, som man med sindsro kan ignorere. Suya, et indianerfolk i Amazonområdet, bruger mere tid på at synge end nogen anden aktivitet. De finder altså sang og musik vigtigt. Alligevel præsterer antropologer at studere folk som dem uden at ofre deres sang opmærksomhed.

Da jeg fik fat i en lp med en stor musiker, som spillede klassisk musik på den sydindiske vina, var jeg straks klar over, at jeg ville derhen, hvor man lavede den slags musik. Sådan indledtes en specialisering i Tamil Nadu i Sydindien. Siden hen fandt jeg i Indien et musikinstrument, som til min store glæde forenede min tidlige interesse for gastropoda, lamellibranchia og musik: Et blæseinstrument, simpelthen en stor konkylie med et hul boret i den spidse ende. Det er et helligt instrument, som hinduer blæser i under tordenvejr for at afværge lynnedslag. Jeg har stadig min store samling af musikoptagelser, men mine musikinstrumenter fra den ganske verden har jeg ét efter ét skilt mig af med, undtagen konkylietrompeten fra Indien. Den indeholder alle mulighederne i svøb.

Lars Kjarholm, antropolog 
